\title{
The Turning towards Neo-Endogenous Rural Development of the Farmers Network : The Case of the Regional Agricultural Cluster Scheme in Asan City
}

\author{
Tae-Yeon $\mathrm{Kim}^{1 *}$ \\ ${ }^{1}$ Department of Environmental and Resource Economics, Dankook University \\ 농민단체 주도의 신내생적 농촌개발에 관한 연구 \\ - 아산시 지역농업 클러스터 정책 사례- \\ 김태연 ${ }^{1^{*}}$ \\ ${ }^{1}$ 단국대학교 환경자원경제학과
}

\begin{abstract}
This paper deals with the novel concept of neo-endogenous rural development which has been applied to explain the contemporary features of the European rural development. The notion of neo-endogenous rural development has been emerged in Europe because the pervious dichotomous concepts of exogenous and endogenous development are no longer useful for explaining the relationship between the local actors and the central or regional administrative organisations. The concept argues that the changing situation of rural regions at the initial stages of endogenous development could only be identified by the concept of neo-endogenous perspectives. Therefore, it tries to apply the concept for the Korean rural development policy which is called Regional Agricultural Cluster scheme. Explaining the development processes and the problems of the farmers group which carried out the project in a local level, this paper argues that the severe conflict between the farmers group and the City Office may be a typical incident of the neo-endogenous development. It expresses the power relations between the local groups and the political managing authority. With the case of the Prundle, it concludes that the neo-endogenous development is the essential stage for all the endogenous development to go through as an transitional one.
\end{abstract}

요 약 이 논문은 2005년부터 2009년까지 농식품부에서 지원하는 지역농업클러스터 사업을 수행한 농업생산자 단체 인 푸른들 영농조합법인의 신내생적 발전과정을 분석한 것이다. 신내생적 발전론은 기존의 외생적/내생적 발전론처럼 발전을 지리적인 내부와 외부로 구분하는 것은 실제 농촌발전과정에서 나타나는 현상을 제대로 설명하지 못한다고 비판하고, 발전의 초기에는 내부와 외부의 자원을 동시에 활용하는 신내생적 발전이 나타나며 실질적으로 발전에 도 움이 되는 자원들을 조절할 수 있는 능력이 가장 핵심적인 요소라고 주장한다. 유럽에서 시작된 이 개념을 우리나라 지역농업 클러스터 사업에 적용해서 살펴봄으로써 지역농업클러스터 사업을 지역에서 실행하면서 나타나는 사업주체 와 행정기관 간의 갈등은 단순히 내생적/외생적인 논란으로는 그 실체를 파악하기 어렵고 신내생적 발전의 개념을 적 용해야 그 장기적인 변화방향을 파악할 수 있다는 것이다. 결론적으로 이 연구에서는 아산의 사례를 통해서 농민단체 가 발전을 주도할 수 있는 능력이 있다면 이들이 시행하는 것은 내생적 발전으로 진화하는 과도기 단계의 신내생적 발전이라고 평가할 수 있다는 것이다.

Key Words : Endogenous, Exogenous, Network, Neo-endogenous development, Regional clusters,

The present research was conducted by the research fund of Dankook University in 2012.

${ }^{*}$ Corresponding Author : Tae-Yeon Kim (Dankook University)

Tel: +82-41-550-3614 email: tykim@dankook.ac.kr

Received January 21, $2014 \quad$ Revised (1at January 29, 2014, 2nd February 4, 2014)

Accepted February 5, 2014 


\section{Introduction}

What is the role of central and local governments in endogenous rural development? What is the effect of endogenous development policy on the area where has already been in processes of endogenous development? There have been a lot of disputes on new ways of regional development policy since 1970 s and it has led to the emergence of the neo-endogenous development in the late of 1990s. Most of the researches and policies have been carried out in the context of Europe and there have been a lot of empirical studies on those issues. However, these are still very controversial issues in the context of Korea in relation to the future of rural development policy.

This is, on the one hand, because Korea is traditionally a centralized and state-led country. Most of rural development programmes so far have been funded by the central government which has power to enforce the implementation at local levels in accordance with the national regulations for administrative and legal procedure. It has provided many rural regions with opportunities to build community buildings, roads and any kinds of facilities for rural residents. However, it has failed to increase their ability to manage the facilities and the development processes which are not only the problems of the previous rural development policy of Korea but also the priorities to be addressed by the current central and local government.

On the other hand, even though the exogenous development policy has been dominated in Korea, it could found the cases of endogenous type of rural development in Korean rural areas which have mostly not been identified by empirical research so far. It is hard to insist any kind of government intervention in the development processes without in-depth knowledge on the cases. In other words, the questions raised above are worth exploring to find out the alternative ways to support such an endogenous development in rural areas.

An OECD[1] report identified a trend in rural development policy which is driven by an increased focus on amenities, pressures for reform of agricultural policy, and decentralizing trends within national governance systems. It suggested the new paradigm involved multi-sectoral approaches to development aimed at identifying and exploiting the varied place-based potentials of rural localities. This trend is also found in Korean rural development policy.

With the influence of the international debate on new approaches to regional development, the previous Korean government (2003 2007) launched a plan for regional balanced development which is based on the idea of endogenous development and the key concept covering major parts of government policies. Naturally it spread out to the Ministry of Agriculture and Forestry (MAF) which has a long tradition of centralized policy implementation. Such an endogenous development idea was applied to the MAF policy for the Regional Agricultural Clusters (RACs) in 2005(MAF, [2]).

Most of agricultural and rural development policies of the MAF have been carried out on the basis of both administrative guidelines imposed by the central government and national regulation of financial management. The RAC scheme naturally was regarded as a trial to change the policy implementation process from top-down to bottom-up approach that would be able to reflect the social and economic situation specific to each region. It has a couple of specific features. One thing is that, with the term of cluster, it seemed to target not only at farming businesses but other social and economic activities related to agriculture in rural areas. The other thing is the name of task force team set up for preparing the RAC scheme "TF team for the Revival of Regional Agriculture", which could be interpreted as a clue that the MAF likely started regional specific agricultural support (MAF, [3]). Therefore, it could be worth to review the scheme in order to find out how the new approach influence on rural development at local levels.

Such an application of the new concept of endogenous development may raise some questions to the Korean rural development policy which has been so far carried out by the lead of central government on the basis of national wide applied regulations.

Firstly, is it possible for the endogenous development to be happened in the extent of centralized policy implementation framework? According to some studies (Hill, [4]; Kim, [5]), a change in public policy may need to subsequent changes in policy objective, approaches, the beneficiary target groups and evaluation indicators in order to sustain the coherency of the policy. Moreover, 
the exogenous and endogenous development differ each other in some key features of idea including main principles, driving forces, function and problems of rural areas, and the focus of the rural development activities (Ward et al, [6]). Therefore, as long as the RAC scheme introduced the endogenous development policy without any changes in policy implementation framework, it may need to find out the effectiveness of the RAC scheme on rural development.

Secondly, what is the role of central and local government in the endogenous rural development policy? Of course, it is natural to ask the possible way of central government support for encouraging endogenous rural development. But it is especially more questionable whether the local government is regarded as the exogenous or endogenous unit. It may generally differ from country to country depending on its local government system. To the extent of Korea, the local government, subordinated historically to the central government for a long time, has been given its legal right of autonomy since 1995. However, many local governments at county level could not help but to depend on the budgetary support from the central government because of their financial difficulties. Thus, most of rural development programmes at county level have been funded through the national policy of the central government which is the same as the RAC scheme. Therefore, it may be important to find out the role of local government in endogenous rural development programmes by close looking at the implementation processes at the country level.

Lastly, does the Korean type of endogenous rural development create proper cases of models of rural development? And what has been happened if it is applied to the already endogenously developed areas? The support of government policy does not always result in good effects on the rural areas. Thus, it is natural to think that the improper policy intervention, in this case the misled endogenous development policy of RAC scheme, may turn out the failure of the policy or worse effects on those which previously developed very well on their own. Therefore, this study examines the effect of RAC scheme on the previously well developed farming groups, Prundle farming cooperative in Asan city, Chungnam Province of Korea.
In order to address those questions, it applies the concepts of exogenous, endogenous and neo-endogenous development. These would be useful to identify the influence of the endogenous and territorial approaches of rural development policy of Korea. In doing so, it firstly reviews the three concepts of rural development. And secondly, it examines the key features of RAC scheme, followed by the historical overview of the development processes of the Prundle farming cooperatives as a case of this research. The next section examines how the Prundle manages networks with other actors in local area and then identifies the problems and reasons of why the Prundle came into conflict with the local government. The findings of this research are summarized in the conclusion.

\section{The Concept of Neo-Endogenous Development}

Why do we need the new concept of neo-endogenous development? It is simply because the previous concepts would not be applicable to current rural economies and societies. Why is that happened and what were the problems with the previous concept? This is because the rural areas have been changed not only in relation to their social and economic situation but also in relation to perception on their way of living and the development. In other words, it has gone the era of modernist paradigm which mainly focused on the growth of economic benefits, which subsequently trickled down to other areas.

The notion of neo-endogenous development is emerged as an effort to explain the changed situation of rural areas in Europe. Lowe et al[7] criticized the both of exogenous and endogenous development. On the one hand, the exogenous development policy which was the classical model of rural development in the post-war period is regarded as an out of date one for the current Western European regions. This is because the European rural areas are now characterized having different characteristics not only in relation to social and economic circumstance but also in the development trajectories of rural areas. The differentiation is also heightened by increasing competition within and between regions to attract or resist external forces of change. Thus, it can be 
argued that universally-applied, state-driven, and top-down approach to rural development is no longer the useful policy to contemporary European regions.

On the other hand, the endogenous development which was regarded as an alternative for the current diverse rural areas is also criticized by its idealistic nature and vague definition. Lowe et al.[7] argued that the notion of local rural areas pursuing socio-economic development autonomously of outside influences may be ideal but is not a practical proposition to European rural areas. It means that the concept of endogenous development may fail to fully explain the rural development processes in reality. Therefore, the both of local and extra-local factors are involved in actual development processes in the capitalist societies.

In order to overcome the limits of the previous geographical dichotomous concepts of the development, Ray[8] suggests a definition of the neo-endogenous development as 'endogenous-based development in which extra-local factors are recognised and regarded as essential but which retains belief in the potential of local areas to shape their future'. From his definition, it tries to identify the features of neo-endogenous development in respect of the previous findings on the exogenous and endogenous development.(Lowe et al. [9]; Kim \&.Lowe, [20])

It may say that in the contemporary rural regions, the development would be started by various motives including not only economic concerns but also social, cultural and environmental factors. In this situation, the key principles affecting on the success of the neo-endogenous development would be the network of the localities. In the course of making internal and external networks, there are diverse reciprocal resources wherever they are within or outside of the localities.

With the resource, the objectives of rural development would create diverse productive and service economies based on environmentally sustainable systems in rural areas. Thus the main problems in achieving the rural development would be inequalities and asymmetries within the network, imbalance local and extralocal control, and the weakness of networks in terms of the low circuits, power, knowledge and capital. Therefore, the development should aim for decentralisation of the administrative power, capacity-building of local actor to steer larger processes and actions and valuing rural areas within wider economic development.

Accordingly, the main features of the neo-endogenous development would be changed into endogenous development when the localities could control the local and extra local resources for the purpose of their own development trajectories. Otherwise, the neo-endogenous development would simply turn into the traditional exogenous and economic centred development when the power of outside localities could control the local resources. In other words, if the central government has great power in development processes of local regions, any kinds of efforts to do the neo-endogenous development will be failed to achieve its own objectives. Therefore, this paper intends to examine the neo-endogenous feature of rural development in the case of Korean rural development policy.

[Table 1] Features of Neo-Endogenous Rural Development

\begin{tabular}{|c|l|}
\hline $\begin{array}{c}\text { Key } \\
\text { principle }\end{array}$ & $\begin{array}{l}\text { - Network. } \\
\text { - Diverse drivers of development }\end{array}$ \\
\hline $\begin{array}{c}\text { Dynamic } \\
\text { force }\end{array}$ & - Interplay of local and extralocal resources \\
\hline $\begin{array}{c}\text { Function of } \\
\text { rural areas }\end{array}$ & - diverse productive and service economies \\
\hline $\begin{array}{c}\text { Major rural } \\
\text { development } \\
\text { problems }\end{array}$ & $\begin{array}{l}\text { - Inequalities and asymmetries within network, } \\
\text { - Imbalance local and extralocal control } \\
\text { knowledge and capital) }\end{array}$ \\
\hline $\begin{array}{c}\text { Focus of rural } \\
\text { development }\end{array}$ & $\begin{array}{l}\text { - Decentralisation, } \\
\text { capacity-building of local actor to steer larger } \\
\text { processes and actions } \\
\text { Valuing rural areas (and resources) within } \\
\text { wider economic development (incubation and } \\
\text { catalyst of growth) }\end{array}$ \\
\hline
\end{tabular}

\section{The Regional Agricultural Cluster Scheme}

There was a lot of dispute on the RAC scheme during the preparation of the scheme. The main thing was about the tautology of 'regional agriculture' and 'cluster'(MAF, [10]). On the one hand, it was raised because the farming activities were naturally clustered for a long time in a certain region. In this sense, the term 'cluster' in agricultural sector could be regarded as the same meaning of the regional agriculture. On the other hand, the term of 
'regional agriculture' for a certain research area has been used as a relative concept to 'national' or 'global' agriculture. With such a ambiguity of the regional agriculture, the argument of tautology was not strong enough to change the term. Anyway, from the series of seminar it was realized that the RAC scheme should have articulate purposes and implementation processes because it was unfamiliar for the people who had been working in the agricultural sector.

With the introduction of the policy from regional development area, it should include not only agricultural activities but also the other development activities for establishing networks and co-operation between local agencies for the first time(MAF, [2]). Unlike the previous policies targeted at only farming activities, accordingly, the policy set up the objectives incorporating development issues which was used in the regional development policy as follows i) to increase farm income by encouraging regional specific farming practice, ii) to development agribusiness in connection with regional culture and tourism, and iii) to establish regional network with relative actors(MAF, [2]). It was expected through this policy that the responsibility and flexibility of regional agricultural policy would be increased and reinforced. As a result, its ultimate aim which was stated dubiously in a policy document was to localizing farming policy and to establishing local governance being able to deal with local issues.

In order to achieve its objectives, the MAF introduced somewhat different implementation structure from the other agricultural policies. Reinforcing the networks between local actors, it firstly introduced the support system for collaborative group of local actors comprised of local government, university and farming corporation. As you can see in [Fig 1], the money flow from the MAF to County office was the same as other agricultural schemes, but the beneficiaries were not solely farming companies but the group of institutions which were interested in the development of the region. Since there had been no budgetary support for the consultative body in traditional agricultural policy, it was a big step forward for the localising agricultural policy.

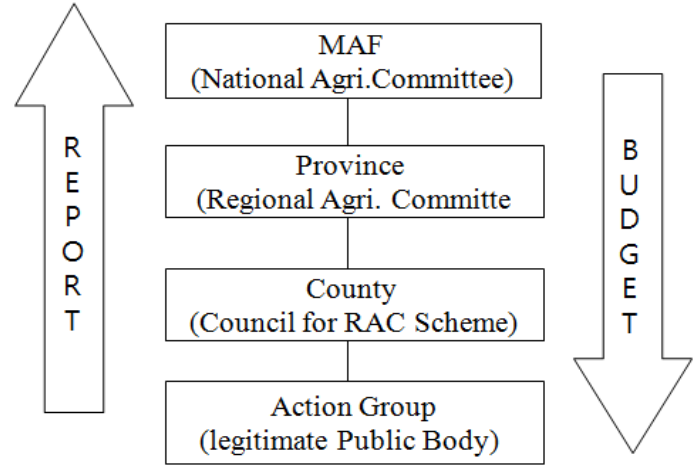

[Fig. 1] Implementation Structure of the RAC Scheme

Since the 2003, the Korean government started to look at the European cases for the reform of development policy. In line with this, the endogenous development was introduced for the regional balanced development. The RAC scheme was also launched in doing so. Accordingly, the RAC scheme had some significant factors which could have led a reform of Korean agricultural policy. There were some features which could be regarded as the application of endogenous development approach. First of all, it tried to incorporate rural issues with agricultural ones which had been in charge of other departments including the Ministry of Health and Welfare, the Ministry of Government Administration and Home Affair, and the Ministry of Commerce, Industry and Energy. It could be a signal for the MAF to take the initiative on the policy for the rural regions. And it was linked with the MAF's lead on the special law for improving living quality of rural residents and then the launch of rural policy.

The second was the decentralization of decision making to regional level. Even though there were some guidelines for making a business plan and use of the budget, local governments (country offices) and the consultation body of local actors could be seen to have power to decide what they wanted to do for their own regions. From such autonomous process, thirdly, it could be expected to form a local network among the local actors which could be developed into local governance. The last one was the multi-annual business plan to make up through the network between local actors. Although it did not have the actions to be taken in detail for the following three years, it could be a good start to maintain 
the development process as planned whatever changed in the government policy.

The endogenous development, however, could not be performed simply by the introduction of new implementation process in a certain scheme, but it actually needed to change the whole system of policy support including breaking stereotype on the concepts and outcomes of development which should be away from the concept of modernization and economic growth-first ideology. From such a perspective, the RAC scheme was criticized by the unchanged support system and regulations. Firstly, it was criticized by the competitive selection process which the applications in the local and central governments were assessed by the experts on agricultural and rural issues. Some of them had a good knowledge on the nature of endogenous development, but some did not. Therefore, the selection of the projects seemed to simply follow the same rules and conditions as imposed on the other policies.

Another one was the unchanged annual budgetary support system. Even though the applications for the RAC scheme were required to make up the multiannual business plan including the detailed breakdown of the use of the budget, however, its actual activities were depended on the budget equally divided annually which might have to spend almost of them within a year. Especially the ways and conditions to use the money were fixed by the national law and audited by the Board of Audit and Inspection. All these problems, finally, stemmed from the lack of legislation which could guarantee the flexible use of national budget for the benefit of local people. In other words, the national administrative system did not match with the effort of the RAC scheme which tried to apply the principles of endogenous development. This kind of barriers of national intervention against performing endogenous development in local areas would be shown in the following sections.

\section{The Development of the Farmers' Networks}

This paper is dealing with the case of a co-operative for environmentally friendly farming - called the Prundle Farming Co-operative (hereafter Prundle) - in Asan City of Chungnam Province. Started the co-operative cultivation of organic vegetables in a village of 200 households in 1977, it has a long history of co-operation by themselves for more than 30 years. With the modest start of their own businesses selling their products directly to consumers, it actually failed to survive in the fluctuated economy and only 6 farmers were left in the end. Its resilience or restoration was made in 1987 by the linkage with a nation-wide consumer co-operative for organic products called 'Hansalim'(Kim, [11]; Lee, [12]). From then on, the member of producers in the Prundle has been dramatically increased from about 30 farmers in 1987 to about 450 farmers in 2005 which becomes the largest farmers co-operative based in a single county in Korea(Prundle, [13]). Its growth was helped by the growth of the Hansalim which was also caused by the recent growth of market on organic products(Hansalim, [14]). Even though they started other business by their own effort, it would not be possible if the Hansalim did not have the nationwide selling network. In this sense, the RAC scheme was the first opportunity for the group to set up his own local network with other actors including universities, local administrative councils and other farming groups. Therefore, it examines the development processes of the network from the view of the Prundle and then tries to identify the problems the RAC scheme incurs.

\subsection{Forming Networks within the Local Area}

The collaboration among local actors was firstly initiated in the course of applying for the RAC scheme. Unlike other schemes which gave money for rather specific capital investment, the scheme required to make a multiannual business plan for 3 years including capital investment and other socio-economic actions. In other words, it was not possible for a single farming group to make up the application but required collaboration with other local organisations and stakeholders. The application for the scheme was initiated by an officer in farming related organisation in Chungnam province. 
[Table 2] The Participants of the Cluster Network

\begin{tabular}{|c|c|c|}
\hline Sectors & Organisations & Function \\
\hline Industry & $\begin{array}{l}\text { - Prundle Agri-corporation } \\
\text { - Hansalim } \\
\text { - Heuksalim Biotech } \\
\text { - Amiwon Agri-corporation } \\
\text { - Asan Agri-corporation } \\
\text { - Eumbong co-op } \\
\text { - Chungnam Agro-techno } \\
\text { Park }\end{array}$ & $\begin{array}{l}\text { - Key actors carrying out } \\
\text { capital investment and } \\
\text { regional innovation } \\
\text { projects } \\
\text { - Production, processing, } \\
\text { market development, } \\
\text { selling, and financing } \\
\text { funds }\end{array}$ \\
\hline
\end{tabular}

Source : Asan City Office, [15].

Various local actors were involved in the course of drawing up the business plan. Even though the Prundle knew what to be assisted for the development of their regional farming, they were not able to make the plan with proper time span and logical explanation. Therefore, people from Asan city office and universities nearby were involved. In addition, the scheme needed to embrace other farming groups in Asan city because it aimed at reinforcing farming related activities as a whole in a region. Thus, there were several meetings for drawing up the multiannual plan and naturally it formed a network among researchers, public servants from Asan City Office and people form farming groups. This was the first clustering network in Asan city consisted of researchers, farmers, and administrative officers who would be the main actors to develop regional agriculture as a whole. Of course, each of them had its own relationship with others for a long time. However, such a relationship was not, indeed, based on the mutual understanding and recognition but one-off advice and collaboration on specific issues. Therefore, the clustering network was expected to contribute on the regional agriculture by way of learning by doing in the course of conducting the programme of the RACs.

The first collaborative work of the network was the multiannual business plan (Asan City Office, [15]) to apply for the scheme. The Prundle led the process of drawing up the plan. They actually had their own business plan for the next 10 years. It contained in which investment should be made and what business activities should be started in the time of 2005, which would be very useful to design the future of organic farming in the Asan area. Accordingly, it was used to make up the plan. Based on the 10-year plan of the Prundle, the network did check up the feasibility and time schedule of the investment and added up some actions in order to extend the effect of the scheme into the rest of Asan area. The application was passed through a couple of deliberation process firstly in the local government and then in the central government and finally selected as one of 20 pilot projects of the RAC scheme in May, 2005(MAF, [2]).

\subsection{Legalisation of the Cluster Network}

According to the law on government budget and account of Korea, a beneficiary of the budget should be registered as a juridical body. After the selection of the pilot project, it was the first thing then that was to set up a legal system for the operation of the project. Since the decision making structure of the cluster network had already been drawn up in the business plan, it was not actually difficult to form the network system but needed an agreement on the legal responsibility of the participant. If the network system changed its legal status to a non-profitable public body, it meant that the participants should take legal responsibility as board members for performing the project. However, it was not hard to get agreements of the participants in spite of their legal responsibility. So, it registered the cluster network as a non-profitable public body, called the Asan Environmentally Friendly Regional Agricultural Cluster(ARAC), in August 2005 (ARAC, [16]). The organisational structure of the body can be seen in the Fig.

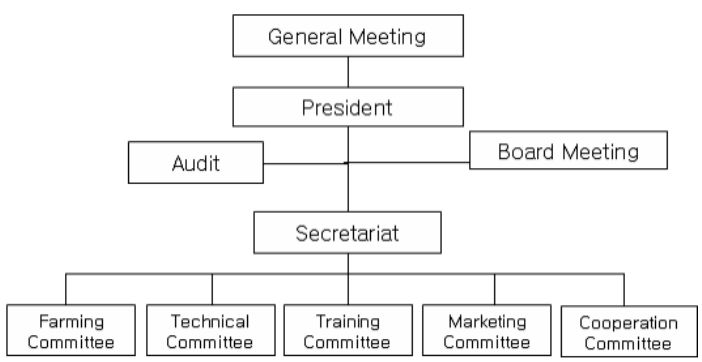

Source: ARAC, [17].

[Fig. 2] The Organisational Structure of the ARAC Network

By the legal registration of the cluster network, the ARAC had a basis to operate the cluster network even beyond the three-year policy period. The registration clearly defined the role and function of each participant. As you can see in the figure above, each section consisted 
of several people from various regional organisations and groups and they had specific tasks to do. Therefore, the participants could get mutual understanding on the situation and future of the environmentally friendly farming in Asan not only through the general meeting but also through meetings of each section.

In addition, it was clear from the figure that the cluster network was initiated by the Prundle because the chairman of the ARAC was the director of the Prundle. The others were participated as board members including the officers from Asan city office. In Korea, the government budget generally flows down to beneficiaries only through local county offices. Thus, it was very remarkable that the local county office provided a kind of private decision making body, ARAC, with the public money on the basis of the decision made by its private board members. Actually it was a purpose of the RAC scheme that was to improve the autonomy of regional agricultural policy by way of forming and using the local governance. Therefore, the different implementation processes taken by the RAC scheme could be regarded as an action to reform against the centralised and universal approach on the budgetary expenditure. However, it turned out to be very naive expectation and judgment in the end and caused conflicts between the participants.

\section{The Conflict within Local Governance}

The pilot project of the RAC scheme in Asan was supposed to start in 2005. Because of the deferred transferring of the budget from central to local government, however, it actually started from 2006. Thus, the ARAC discussed the appropriateness of the monthly and annual schedule of the plan, adjusted individual projects in detail and decided the groups carrying out each project. It was a necessary step for the ARAC to prepare for the performance of the scheme in the region. However, as soon as the Asan city office received the budget from the central government, she started to think of the legal or traditional way to fund the government projects. It caused several conflicts between the participants, mainly between the Prundle and the Asan city office.

\subsection{The Initiative in Decision Making: Legitimate Procedure vs. Regional Initiation}

During the whole process of the preparation, the Prundle organized all of the meetings between the participants, paid all the necessary cost and initiated the ARAC on the based on its previous producer organization. Since the MAF tried to apply the endogenous approach and authorized the local cluster network(ARAC in this case) to implement the scheme, the ARAC could flexibly handle the regulation considering its regional specific circumstance. However, it was changed in the early 2006 when the Asan city office received the budget from the central government and tried to take over the initiation. Actually the budget would straightly go to the ARAC from the Asan city office according to the administrative regulation which meant the Asan city office should have responsibility for the spending. In other words, the Asan city office should make up reports on the budgetary spending and sometimes take an inspection from the central government or the National Audit Office(Chungnam Province Office, [18]). Instead of authorizing the ARAC to use the project budget by its own decision, therefore, the Asan city office from then on started to follow the legal administrative procedure and proper regulations on the national account.

The Asan city office set up a council for the RAC in doing so that was called the Council for the Asan Environmentally Friendly Regional Agricultural Cluster (CARAC). Although the manager of the agricultural policy and the chief of environmental friendly farming division in the Asan city office were participated in the ARAC as a board member, it launched another decision making body led by the City Office. The CARAC consisted of the more delegates of farming organisations and groups in Asan city than those of the ARAC (CARAC, [19]). It actually had lawful power to authorise the annual plan and the expenditure on every project. Consequently, the ARAC that was set up not only by the farmers own initiation but also by the effort of voluntary participants, which could be regarded as an action of endogenous development, lost its roles and functions in discussing and monitoring the performance of the RAC scheme in the region.

The CARAC comprised of 32 members which was 
more that those of the ARAC. Looking at the member organizations of the CARAC, it covered by and large influential agricultural organizations in Asan even those which had no information on the cluster scheme were participated in the group. Unlike local agricultural co-operatives, the Asan branch of the National Agricultural Co-operatives did not have any knowledge on the region with most of the staffs were dispatched by the Headquarter. And some farmers groups such as the Asan Farmers Union and Asan Farmers Federation were also a kind of political action groups rather than those of local farmers association. Moreover, it included individual farmers and a couple of organic farmers groups who initially rejected to participated in the cluster application. This seemed to apparently show that the initiation of the Asan city office might concentrate more on equity and the public opinion on the scheme implementation rather than practical performance of the scheme and the long term development of the regional agriculture. In other words, the formation of the CARAC turned out an effort to avoid any kind of legal responsibility and to lessen any kind of complain from other farmers and groups. Therefore, the CARAC was simply a legal step to implement the RAC scheme following the rules set by the central government.

[Table 3] The Members of the CARAC

\begin{tabular}{|c|c|c|}
\hline Sectors & Organisations (persons) & $\begin{array}{c}\text { No. of } \\
\text { Participants }\end{array}$ \\
\hline Industry & $\begin{array}{l}\text { - Prundle farming -cooperative(1) } \\
\text { - Amiwon Agri-Corporation(1), } \\
\text { - Asan Agri-corporation(1), } \\
\text { - National Agricultural Cooperative } \\
\text { - Asan branch(1), } \\
\text { - Songak Co-op(1), } \\
\text { - Youngin co-op(1), } \\
\text { - Asan livestock co-op(1), } \\
\text { - Asan farmers federation(1), } \\
\text { - Asan farmers union(1), } \\
\text { - Agricultural guide federation(1), } \\
\text { - Hansalim Cheonan-Asan Ltd(1) } \\
\text { - Organic producers group(2), } \\
\text { - Organic producers in Asan(6) }\end{array}$ & 20 \\
\hline Academia & $\begin{array}{l}\text { - Dankook Uni(3), } \\
\text { - Soonchunhyang Uni(1), } \\
\text { - Cheonan Yonam College(2), } \\
\text { - Hoseo Uni.(1) }\end{array}$ & 7 \\
\hline Government & $\begin{array}{l}\text { - Asan City Office(3) } \\
\text { - Agricultural Technology Center(1) } \\
\text { - Asan City Council(1) }\end{array}$ & 5 \\
\hline & Total No. & 32 \\
\hline
\end{tabular}

Source : CARAC, [19].
Since the CARAC took over the initiation of the RAC scheme in Asan, the implementation processes were suddenly changed like a project of the Prundle by the support of the Asan city office which was the same style of policy as the other agricultural policy. Because the member did not have enough knowledge on the RAC scheme and the interest in the development of Asan region as a whole, they just listened the presentation on the annual plan, checked the cost to spend on each project and casted a couple of questions. There would be no problem even if the ARAC could play its roles and functions set at the initial stage. Without any power of decision making and monitoring, however, its actions would not be in need. Furthermore, it turned out that the ARAC's function would do report to the CARAC for their decision making. Therefore, it stopped the action of the indigenous and voluntary group, the ARAC, and the genuine discussion for the long term development of the rural development in Asan region. The CARAC decisively prevented the cluster network from developing the local governance at the very early stage.

\subsection{Conflict by the Replacement of Staffs in the Asan City Office}

During the 3-year period, there was several replacement of staffs in the agricultural department of the Asan city office. Some were scheduled replacement which happened once in a year as usual and others were ad hoc. Even though those were not happened mainly by any blames, it reflected the relatively less preferred position of agricultural department in the city office. Anyway, because of the rather frequent replacement in the division of environmental friendly farming, it was hard to maintain the consistency of the administrative procedure. Despite following the rules and regulations set by the central government, it was natural that the officers in charge had some rooms for authorizing their judgment during the scheme administration. Thus, the frequent replacement caused not only inconsistency of the administrative procedure but also let to the lack of recognition on the RAC scheme which could harm the collaboration between the local government and the farmers group.

With the initiation of the Asan city office, there were not many farmers groups involved in the RAC scheme. The national regulations on the government schemes did 
not allow other farming groups in the region to conduct a project without any responsibility of the main performance group, the Prundle. Since the RAC scheme was mainly operated by the Prundle and most of the projects were actually done for their own businesses, thus, it also occurred jealous of other farming groups. They saw the development of the Prundle as a result of government supports and the political actions of the leading members of the Prundle. From such an environment, there emerged hostile actions against the Prundle. Actually the leader of the Prundle was prosecuted for the misappropriation of fund by the local farmers. Even though there has been no proof found for the following 2 years, it was connected with the RAC scheme administration of the Asan city office. In other words, it coincided with the replacement of the public servants which resulted in severe conflict between the Prundle and the Asan city office.

Since the accusation of the competitive farmer, the offices who were in charge of the RAC scheme applied more strict rules and regulations on the projects. Even they went back to check the past performance which caused a case of the conflict between them. It was about the agricultural storehouses which comprised of three sections which had been done by single whole project. According to the government regulation, that project should be separated by three different projects which should be done by three different companies, otherwise it should have three different contracts and tenders. This was because two sections of the building were funded by the other agricultural policies. However, one of the aims of the RAC scheme was to integrated agricultural schemes to increase the synergy effect of the policy. Therefore, the three related projects were combined into a single project and commissioned by a constructing company. It was negotiated with the previous staffs and decided to make it simple.

The construction was finished in the middle of 2007 just before the staff replacement, but it became suddenly problematic issues by the replacement. The new staffs did not follow the predecessors actions and even rejected to admitted it which could be attributed to their mistake. Therefore, they asked the Prundle to amend the old document with new one applying the guideline of agricultural policy existed. The main documents to amended were the records of three different tenders showing that the construction company bade the lowest price and the detailed calculation of the construction costs. It did not only follow the rules and regulations of the government supports but also reinforced to avoid any kind of responsibility they could get. Since most of the projects was finished before getting the financial support, the Prundle had to follow the instruction of the new staffs in order to get the rest of money. Most of the documentation works had been done by the Prundle and the construction company which underwent the conflict between the two organizations.

It superficially happened by the replacement but it actually caused by the lack of recognition on the nature of scheme. The staffs in the Prundle said:

"I have never heard that the projects by the RAC scheme differ from the ordinary agricultural schemes. The predecessor just directed me to follow normal administrative procedure"

It was occurred partly by the malfunctioning of the cluster network, ARAC, with the taken over the CARAC in the very beginning of the scheme. Without any knowledge what was happening between the two actors, nobody could help them to solve the conflict. Consequently, it naturally resulted in the lack of mutual understanding which affected on other actors.

\section{Conclusion}

It is important to note that the Regional Agricultural Cluster scheme has tried to apply a novel policy approach to traditionally centralised agricultural policy of Korea with the perspective of the endogenous development. On the one hand, it could be said that the RAC scheme has achieved its objectives because most of the businesses funded by the scheme are still in operation. On the other hand, it failed to institutionalize the endogenous approaches to the agricultural policy in Korea. From the endogenous rural development perspective, the former would not be the direct outcomes and ultimate aims of the policy support, but the latter must be the failure of the policy. 
Talking about the dichotomous classification of exogenous and endogenous development, this case may show that the endogenous development would be impossible in the case of the involvement of the central government support. Especially, it would be even harder to have the features of the endogenous development if the implementation processes and the use of government budget were guided by the national regulations. This case shows that even though the central government would change its ideology and logical basis into the endogenous development, it would not achieve the endogenous development until it committed fundamental reform at least in the policy implementation processes. Moreover, in order to achieve the endogenous development, it should not only be accompanied by the change in perception of, but also provided articulate or flexible administrative power to those who were in charge of rural development in the local governments.

Should it say, thus, that the RAC scheme may have the same effect as those achieved by the exogenous approach? Nevertheless, it could find somewhat different results from those by the previous policy support. It is through the experience on the implementation processes that the RAC scheme may increase the awareness of the farmers group on the understanding and attitude of the civil servant in the local governments. In other words, the farmers group who would be one of the potential actors of the endogenous rural development may increase its capacity to cope with the policy actions of the local government and maintain collaboration with those who are in charge of the policy. The staffs of the Prundle in this case fully completed the requests of the local government, which could be regarded as the proof.

Consequently, the farmers group as an actor of the regional development may have valuable experience as to how they manage the relationship with the local government in order to achieve their development objectives. Although the actual effect of their experience would be gone with the replacement of the staffs in the local government, their ability to deal with the civil servants must be improved. Such results are not only different from those of the exogenous development but also very hard to explain by the endogenous perspectives. Therefore, it requires to import other conceptual framework of the neo- endogenous development. The term could be used to describe the transitional aspects of the local initiative development. In other words, the concept of neo-endogenous development is useful to identify the early stage of endogenous development which could be ignored as it is supported by the central government or the extra local resource. Otherwise, it might be easily regarded as an exogenous type of development.

\section{References}

[1] OECD, The New Rural Paradigm : Policies and Governance. Paris: OECD, 2006.

[2] MAF, Policy for the Regional Agricultural Clusters, Ministry of Agriculture and Forestry, 2005.

[3] MAF, Plan for the setting up and management of Task Force Team for the Regional Agricultural Clusters, Ministry of Agriculture and Forestry, 2004.

[4] Hill, B., Introduction to Agricultural Economics, CAB International. London, 1987.

[5] Kim, T., Family farm models for rural development: the case of the Northern Upland Objective 5(b) areas in the $U K$, unpublished Doctoral thesis, University of Newcastle upon Tyne, 2004.

[6] Ward, N., J. Atterton, T, Kim, P, Lowe, J. Phillipson and $\mathrm{N}$. Thompson, Universities, the knowledge economy and the 'neo-endogenous rural development, Discussion Paper, No. 1, Centre for Rural Economy, University of Newcastle upon Tyne, 2005.

[7] Lowe, p., J. Murdoch, and N. Ward, "Beyond endogenous and exogenous models: Networks in rural development", in Van der Ploeg, J.D. \& Van Dijk, G. (eds.) Beyond Modernization: The Impact of Endogenous Rural Development, Assen, Netherlands, Van Gorcum, 2005.

[8] Ray, C. Culture Economy, Centre for Rural Economy, University of Newcastle upon Tyne, 2001.

[9] Lowe, P., C. Ray, N. Ward, D. Wood \& R. Woodward, Participation in Rural Development: A Review of European Experience, Research Report, Centre for Rural Economy, University of Newcastle upon Tyne, 1998.

[10] MAF, The First Public Hearing for the Regional Agricultural Clusters Policy, Ministry of Agriculture and Forestry, 2004.

[11] Kim, T., "The embeddedness of farmers groups in rural areas : the case of organic farmers group in Asan City", Korean Journal of Organic Agriculture. Vol. 15, No. 2, 
p131-150, Korean Association of Organic Agriculture. 2007.

[12] Lee, H. "The beginning and development of Asan Environmental Regional Agriculture", Workshop of the Asan Environmentally Friendly Regional Agricultural Cluster, 28-29 July, 2006, Asan Environmentally Friendly Regional Agricultural Cluster. 2006.

[13] Prundle, Annual report for the general meeting, Prundle Agricultural Cooperative Ltd, 2003 2010.

[14] Hansalim, Annual report for the general meeting of Asan Producers Association, Hansalim Producers Association in Asan City, each year.

[15] Asan City Office, Plan for the resource cycle environmental regional agricultural clusters in Asan", Asan City. 2005

[16] ARAC, Discussion material of Asan Environmentally Friendly Regional Agricultural Cluster 2005, Asan City, 2005.

[17] ARAC, Discussion material of Asan Environmentally Friendly Regional Agricultural Cluster 2006, Asan City, 2006.

[18] Chungnam Province Office, Monitoring for the Regional Agricultural Cluster, Discussion Material of Supporting Committee for the Chungnam Regional Agricultural Cluster, 2006.

[19] CARAC, Discussion material of Council for the Asan Environmentally Friendly Regional Agricultural Cluster, Asan City, 2006.

[20] Kim, T. and P. Lowe, "Operationalising the Concept of Neo-Endogenous Rural Development: An Alternative Method Responding to Globalisation", Space \& Environment, Vol.22, No.1, pp. 115-161, Korean Association of Space and Environment Research, 2012.

\section{Tae-Yeon Kim}

[Regular member]

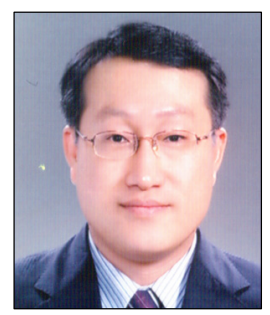

- Feb. 1995 : Korea Univ., Agricultural Economics, MS

- May. 2004 : Newcastle Univ, UK, Agricultural Economics, $\mathrm{PhD}$

- Mar. $2005 \sim$ current : Dankook Univ., Dept. of Environmental and Resource Economics, Associate Professor

$<$ Research Interests $>$

Agri-environment, Rural Development, Food Industry, EU and UK Agricultural Policy 